\title{
Florbela erótica*
}

\section{Maria Lúcia Dal Farra**}

\section{Resumo}

Este artigo trata, como sugere o título, do erotismo da poética de Florbela Espanca. A Virgem florbeliana agasalha em seu regaço o paradoxo do bem e do mal concernente à mística da mulher. Esse é o seu modo de declarar que a porção demoníaca do feminino, esse corpo estranho, com seus valores noturnos, esse continente negro, acepção do ser sexuado, da portadora do pecado e da sedução, da desordem e do desenfreado - não pode ser expurgada sequer da imagem mais celestial que erige para si mesma.

Palavras-chave: Florbela Espanca, Poesia, Crítica Literária.

\footnotetext{
" Recebido para publicação em abril de 2002.

*** Universidade Federal de Sergipe.
} 
Florbela erótica

\author{
Erotic Florbela
}

\begin{abstract}
As the title suggests, this article deals with the eroticism in Florbela Espanca poetics. The florbelian virgin shelters in her bosom the paradox of good and evil relative to the feminine mystique. That is her way of declaring that the demoniac portion of the feminine, that strange body with its nocturnal values, that black continent, representation of the sexed being, carrier of sin and seduction, of disorder and of the unbridled - cannot be freed even of the most celestial image it erects for herself.
\end{abstract}

Key Words: Florbela Espanca, Poetry, Literary Criticism. 
Após a instauração do busto de Florbela no Jardim Público de Évora, em 18 de junho de 1949, outros detratores, encorajados pelo apoio da Igreja Portuguesa, dirão, por exemplo, que sua obra "é, moralmente, perniciosa. E isto, mesmo sem tomarmos em consideração a ruína, a miséria, o péssimo exemplo da sua vida privada"; além disso, mesmo a memória de Florbela seria irrecuperável, visto que a escritora não soubera, como o fez Bocage, professar o "magnífico e sincero ato de contrição que o nobilitou e libertou".

Outro de seus aferrados opositores, conferindo total ilegitimidade à instauração do busto, vai mais adiante, declarando peremptoriamente que levantar

uma estátua a uma mulher cuja obra reflete uma posição perante a vida, diametralmente oposta à que está na própria base da Constituição do Estado Português, é praticar um ato de sabotagem, porque representa uma traição ao que se jurou defender". ${ }^{2}$

Saiba-se, portanto, o que foi Florbela para o salazarismo: o anti-modelo do feminino, da concepção de mulher - e nisto reside, sem dúvida, a força mais primária da sua obra, cuja lucidez indomável questiona, insurrectamente, a condição feminina e os históricos papéis sociais conferidos à mulher. Aliás, o sábio crítico Vitorino Nemésio teve extrema lucidez a respeito da grave ameaça que isso significava para o salazarismo, pois que ele se dava conta

1 São estas as palavras de Narino de Campos, à p.18 da sua obra $A$ poesia, $o$ drama e a glória de Florbela Espanca (Lisboa, Edição do Autor, 1955), dedicada "à memória do bondosíssimo Sr. Dom Manuel Mendes da Conceição Santos, que foi Arcebispo de Évora", nome que encima a mesma fundação que subsidiara, em 1952, a publicação do livro de José Augusto Alegria, que cito a seguir. Ambos os volumes vêm a lume como desagradada resposta do salazarismo à referida instalação do busto de Florbela.

2 Cf. Alegria, José Augusto. A poetisa Florbela Espanca. O processo de uma causa. Évora, Edição do Centro de Estudos D. Manuel Mendes da Conceição Santos, s.d. 1952, p.164. 
Florbela erótica

de que Florbela, além do mais, na sua obsidiante identificação com a charneca e na auto-investidura das raízes regionais, continha suficiente carga mitológica capaz de fazer de si a própria alma da planície alentejana. Assim, ainda em 1949, ele insistia em dizer que compreendia, sim,

compreendo bem as relutâncias $e$ resistências que retardaram a imagem de mármore nos calmos jardins de Évora. A Musa Alentejana imaginada pelo Conde de Monsaraz; a Condessina, fantasiada e desfigurada por Fialho; o gênio da planície, filosofado por Sardinha, afinal eram ela! $\mathrm{E}$ as pessoas, as multidões, o censo demográfico dificultam naturalmente a consagração das ninfas que foram de carne e osso, e que viveram no meio dos mortais. ${ }^{3}$

De fato, já em 1941 Manuel da Fonseca, o saudoso e tão sensível poeta, contista e romancista alentejano, dedicara um longo e expressivo poema à Florbela em que ela emerge como uma errante sem descanso, de atalaia na torre alta do Castelo, com os seus olhos feitos faróis a indicar o rumo, ou pelas estradas de sol ou de lua do Alentejo, pela charneca, pela planície, pelos montados, pelas searas, em busca de justiça para os seus: os campaniços, os ganhões, os malteses. Florbela "sabia tudo/ que há no coração da gente" e esbanjava "braçados cheios/ da grande vida que tinha". Todavia, a cidade onde viveu não a queria, de modo que ela por jogar-se "às estradas da vida/ caminhos do Alentejo": ali, sim, com que prazer, era querida e compreendida! Mas um dia, cansada de dar a tanta vida que tinha, Florbela adormeceu. Eis que passava a Senhora Dona Morte, que, vendo aquela moça tão indefesa, "com ternura a ergueu": então, todos deixaram seus afazeres para assistirem ao grande prodígio que se deu. Diante de Florbela, os ceifeiros "sentiram/ que estavam bebendo/ água fria da fonte;// cavadores pensaram/ que tinham herdado/ a grande courela;// malteses juraram/ haver descoberto/

${ }^{3}$ Cf. NEMÉsIo, Vitorino. Florbela. Diário Popular, Lisboa, 29 de junho de 1949. 
uma Estrada Nova!;// e as moças dos montes/ tremeram de espanto/ como se na noite/ um homem viesse/ tocar-lhes nos peitos!...

\section{E Florbela passando \\ Parecia levada \\ Na vela da saia!}

Mas Florbela já despertou: a sombra andante da árvore não é sombra, é Florbela errando inquieta; o calor que vem de dentro da terra não é o lume do sol, é o cio que vem dos seios de Florbela; a calma que cai da noite, quando o poeta tomba exausto de procurá-la - é a mão de Florbela tocando na sua fronte. ${ }^{4}$

$\mathrm{O}$ poema de Manuel da Fonseca registra precisamente o flagrante de transformação da mulher em mito, transmutação poética em extremo difícil de ser anulada ou ignorada pelos difamadores de plantão. Daí que, à luz desta obra, por exemplo, se entenda a forte carga despedida contra a poetisa por Alegria.

Assim, também a propósito dessa sua gravíssima (mas tão valiosa!) agressão, vale a pena examinar de onde nasce a pecha de imoralidade e de inconstitucionalidade que o autor aponta em Florbela. A obra que lhe serve de base é composta sobretudo pelos poemas póstumos publicados por Guido Battelli (e que imperdoavelmente! - rápido se transformaram num boom editorial), acrescidos dos dois volumes de poesia que Florbela ainda publicara em vida. Trata-se, portanto, de Livro de mágoas (1919), de Livro de Sóror Saudade (1923), de Charneca em flor (1931) e de Reliquiae (1931).

Muito antes de 1952, ano em que Alegria publica esse volume, toda a obra poética de Florbela havia sido reunida pela Livraria Gonçalves de Coimbra sob o título de Sonetos completos, estampando justo como prefácio o precioso ensaio de José Régio, intitulado "Sobre o caso e a arte de Florbela Espanca", que

4 Cf. FonseCA, Manuel da. Para um poema a Florbela. Poemas completos. Lisboa, Portugália Editora, 1969, pp.121-135 
Florbela erótica

conferira o golpe de misericórdia na polêmica contra a poetisa, que se comprazia em identificar rasteiramente sua vida com suas produções. Régio elucidara, então, que era impossível, através da obra de Florbela, conhecer a sua história pessoal ou a sua biografia, visto que o ser que nasce dessa produção resulta apenas da convincente expressão literária que Florbela, enquanto artista, imprime a seus versos - o que significa que a mulher que dessa obra emerge é tão-só o fruto do poder encantatório da verossimilhança, sendo precisamente isso o que torna estética essa poesia. $^{5}$

Malgrado tal defesa, que data de 1946, a insistência em estigmatizar a mulher homenageada pelo busto persevera, como se pode constatar através do volume de Alegria e de Narino de Campos, por exemplo. Como, nessa altura, da prosa de Florbela Espanca apenas o livro de contos dedicado à morte de Apeles, As máscaras do destino, havia sido publicado (em 1931), e como, nele, nada de censurável a moral salazarista havia farejado, salvo o excessivo amor dedicado ao irmão, fato que desencadearia a baixa suspeita de relaçóes incestuosas, carentes, todavia, de quaisquer comprovações plausíveis no âmbito daquele volume -é sobre a sua obra poética que o ataque dos seus detratores continua sendo desferido. Sim, porque, para eles, a produção lírica de Florbela se apresentava como um vasto e fértil campo onde era possível colher abertamente e à vontade tanto exemplos da declaração de cio dessa mulher que, como se viu, sabota a sagrada Constituição Portuguesa, quanto flagrantes de uma vida erótica insuportável à pudicícia salazarista - e a qual me empenharei em desdobrar para que o leitor possa avaliar a profundidade das acusações.

É possível que um dos primeiros vestígios de erotismo na poesia de Florbela Espanca se exponha não pela excedência ou pelo transbordo, mas tão-somente pelo seu avesso: pelo

${ }^{5}$ Cf. RÉGIO, José. Sobre o caso e a arte de Florbela Espanca. Sonetos completos. Coimbra, Livraria Gonçalves, 1946, pp.5-15. 
comedimento, pelo retiro, pelo silêncio. No lugar do sinal de mais, o de menos. Mas essa subtração, quando averiguada mais de perto, se mostra uma camada apenas aparente, já que diz de fato respeito a uma inaptidão, a uma incapacidade que é muito típica do erotismo: a de expressá-lo com propriedade. Primeiro, porque, para proferir o erótico é preciso derrubar barreiras, estilhaçar a permissão, visto que é de tabu social que se trata - e era assim, pelo menos na época em que Florbela ensaiava fazê-lo. Transgredir é, portanto, a única lei viável para os arroubos sensuais. E depois porque, sendo a atividade erótica aquela que ocupa por inteiro o sujeito, ou ele deixa de fruir o seu momento prazeiroso com o fito de poder comunicá-lo com precisão, ou a ele se entrega desmesuradamente sem direito de voz.

$\mathrm{O}$ que ocorre com o erotismo inicial da sua poética é que quando a poetisa, atormentada pela mordaça social que a impede de manifestar sua libido, se obriga a calar - a energia investida nesse ato de mudez acaba por ocasionar nela uma espécie de astenia física e moral, uma afecção psicológica, a que, acertadamente, ela nomeia "neurastenia". O soneto do Livro de mágoas, que ostenta este título, dedica-se ao triste destino daqueles que se encontram à mercê do interdito e, neste caso extremo, nem mesmo os elementos da natureza, tão aliados da poetisa, conseguem se desvencilhar da impotência de voz de que também são acometidos, impedidos de expressar, ainda que delegados por ela, aquilo que tanto a oprime. ${ }^{6}$ Todavia, em mais de dúzias de poemas dispersos, sobretudo, pelas suas últimas obras, a reivindicação de cio feminino se faz ouvir com todo o seu cortejo de vibrações, de poética dos cinco sentidos, de palheta de colorações as mais vivas, onde o rubro, numa modulação que atinge o púrpura, se oferece como a tonalidade emblemática da paixão. É possível, pois, vislumbrar na poética de Florbela uma

${ }^{6}$ Cf. Dal Farra, Maria Lúcia. (org.) Neurastenia. Florbela Espanca. Poemas. São Paulo, Martins Fontes, 1966, p.141. Daqui por diante, sempre que nomear um poema, remeto o leitor às páginas referentes nessa edição; sempre que houver negritos no corpo dos poemas reproduzidos, a responsabilidade é minha. 
Florbela erótica

espécie de roteiro sensual que desemboca, creio eu, numa perfeita epifania sexual - para completo escândalo daquele tipo de leitor...

O rubro coração, erguido ao alto, num impulso de dádiva, como no ato hierático do ofertório, está no princípio desse trajeto. Num poema de Charneca em flor, onde impera a imaginação do movimento, o coração é situado ao lado dos "Nervos d'oiro", título do soneto, como o coadjuvante direto de Florbela na captação da matéria prima fundamental para a sua arte. Reproduzo-o:

Meus nervos, guizos de oiro a tilintar

Cantam-me n'alma a estranha sinfonia

Da volúpia, da mágoa e da alegria,

Que me faz rir e que me faz chorar!

Em meu corpo fremente, sem cessar,

Agito os guizos de oiro da folia!

A Quimera, a Loucura, a Fantasia,

Num rubro turbilhão sinto-As passar!

O coração, numa imperial oferta,

Ergo-o ao alto! E, sobre a minha mão,

É uma rosa de púrpura, entreaberta!

E em mim, dentro de mim, vibram dispersos,

Meus nervos de oiro, esplêndidos, que são

Toda a Arte suprema dos meus versos! (p.241)

Semelhante ao radar, os nervos, associados ao devaneio do diáfano, do ligeiro e do sonoro, ditos "guizos de oiro a tilintar", se impõem, ao lado do coração, como os condutores da emoção, como os aparelhos de sensitividade que produzem os seus versos. Através, portanto, desses nervos, a poetisa diz receber a "estranha sinfonia" composta pela harmonização da volúpia, mágoa $e$ alegria, enfim, a partitura de tudo o que a faz experimentar o dinamismo do choro e do riso. Mas os nervos, tão preciosos e valorizados pela simbólica do ouro, nada seriam se não houvesse o concurso do coração - esse centro das moradas interiores. 
Maria Lúcia Dal Farra

Ofertado como uma rosa de púrpura entreaberta, ele se torna, então, apto para apreender as vibrações do mundo.

Uma vez conhecidos o coração e os nervos enquanto instrumentos de trabalho de Florbela, cumpre lembrar que a condição feminina jamais é esquecida dentro da dinâmica erótica. Num devaneio voluptuoso ascendente, que dá a tonalidade geral a um outro soneto de Charneca em flor, intitulado "Mais alto", o percurso de busca da graça, de alcance da espiritualidade e da pureza vai tangenciar precisamente essa questão. Ali, a altura é almejada como degrau de ultrapassamento das fronteiras do real e da vida, como método de expurgação do próprio eu atormentado, como forma de excedência e de extrapolação da identidade, numa via ascética de quase desencarnação. Todavia, a dialética do leve e do pesado faz comparecer, ao lado dos valores de luz, sonho, orgulho, águia, divindade, duas expressões de peso relativas à vida: a dor e o mal que, em princípio, puxam o impulso ascendente para baixo. Observe-se:

Mais alto, sim! Mais alto, mais além

Do sonho, onde morar a dor da vida,

Até sair de mim! Ser a Perdida,

A que se não encontra! Aquela a quem

O mundo não conhece por Alguém!

Ser orgulho, ser águia na subida,

Até chegar a ser, entontecida,

Aquela que sonhou o meu desdém!

Mais alto, sim! Mais alto! A Intangível!

Turris Ebúrnea erguida nos espaços,

À rutilante luz dum impossível!

Mais alto, sim! Mais alto! Onde couber

O mal da vida dentro dos meus braços,

Dos meus divinos braços de Mulher! (p.240)

Mas em Florbela a dor tem um sentido ambíguo porque, malgrado tudo o que encerre de sofrimento, mágoa, contrariedade 
Florbela erótica

e força rejeitada, exprime, em contrapartida, uma identificação de gênero, é coisa de mulher - valor, portanto, inabdicável. Assim, contrariamente ao corrente, "a dor da vida" representa um supremo bem, visto que é a matéria prima, a força produtiva dos seus poemas. ${ }^{7} \mathrm{O}$ fato é que, nesse impulso ascensional, Florbela devaneia em se tornar a Intangível, a Turris Ebúrnea, uma Virgem Maria envolvida pela luz brilhante e incorruptível dum impossível. Mas trata-se de uma Virgem que, em lugar de pisar "o mal da vida" - simbólica da serpente bíblica, associada à figura de Lilith $e$ de Eva - , em vez de calcá-la sob os seus pés, deseja, ao contrário, acolhê-la nos seus braços, nos seus já "divinos braços de Mulher".

Assim, o que a Virgem florbeliana agasalha em seu regaço é o paradoxo do bem e do mal concernente à mística da mulher. Esse é o seu modo de declarar que a porção demoníaca do feminino, esse corpo estranho, com seus valores noturnos, esse continente negro, acepção do ser sexuado, da portadora do pecado e da sedução, da desordem e do desenfreado - não pode ser expurgada sequer da imagem mais celestial que erige para si mesma.

Em "Blasfêmia", um dos primeiros sonetos do póstumo Reliquiae, a condição feminina reaparece, mas agora enfocada naquilo em que ela questiona os papéis sociais destinados à mulher. Aparentemente, a porção de transgressividade, própria do ato voluptuoso, comparece neste poema porque a amada se equipara a Deus quando se espelha no amante - daí o título, que denuncia o ultraje à divindade. Nessa peça em que o silêncio é de ouro, a indicar recolhimento e retiro, justo para preparar a fruição amorosa, que é sempre muda - a imagem que Florbela faz de si, "um jardim", "um pátio alucinante de Granada", expande a metáfora paradisíaca que já prevalece na contramão da semântica

7 Trato pormenorizadamente deste aspecto na introdução ao já citado livro de poemas de Florbela, como também no estudo contido na edição do primeiro manuscrito de Florbela Espanca, o Trocando olhares (Lisboa, Imprensa Nacional/Casa da Moeda, 1994, estudo introdutório, estabelecimento de texto e notas de Maria Lúcia Dal Farra), para os quais remeto o leitor. 
do título. De fato, espaço de potências florais, lugar de engendramento do que emana da terra e aponta para os céus, o referido pátio de origem muçulmana, com sua fonte central, contém o microcosmos do paraíso, numa aliança entre os quatro elementos.

Silêncio, meu Amor, não digas nada!

Cai a noite nos longes donde vim...

Toda eu sou alma e amor, sou um jardim,

Um pátio alucinante de Granada!

Dos meus cílios a sombra enluarada,

Quando os teus olhos descem sobre mim,

Traça trêmulas hastes de jasmim

Na palidez da face extasiada!'

Mas o que interessa sobretudo reter neste soneto é a maneira de espelhamento da amante no amado, que se confessa a luz do rosto dele, a expressão de suas mãos de estirpe, a ponto de considerar que os beijos que ele lhe oferece agora já foram, antes, dela mesma. Ora, do ponto de vista amoroso, tais asseverações fazem parte da galanteria característica do ato de sedução, aliás, apanágio masculino; todavia, do ponto de vista da condição feminina, quem sabe seja esta a blasfêmia que o poema aponta, uma vez que, na tradição ocidental, é a mulher o espelho do homem - e não o contrário, como ocorre neste poema:

Sou no teu rosto a luz que o alumia,

Sou a expressão das tuas mãos de raça,

E os beijos que me dás já foram meus!

Em ti sou Glória, Altura e Poesia!

E vejo-me - milagre cheio de graça! -

Dentro de ti, em ti igual a Deus!... (p.277)

Uma vez expostos, pois, os instrumentos de trabalho e alguma da matéria prima da escritora, sigo direto no encalço da 
Florbela erótica

maneira como ambos confluem para o devaneio erótico. $\mathrm{E}$ principio pela realização erótica ainda intimidada, como é o caso de um dos sonetos iniciais de Charneca em flor, aquele intitulado "Se tu viesses ver-me...", que se efetua por meio de uma grande elipse lacunar. As reticências do título já preparam o nosso espírito, insinuando introduzir a oração principal que essa condicional anuncia. Todavia, a sugestão será, já no corpo do poema, tão trabalhada e repleta de meandros, tão prenhe de promessas dadivosas e tão significativa, que vai preencher os dois quartetos e os dois tercetos, de modo que não sobra, de propósito, ao soneto, espaço para proferir o verdadeiro alvo do convite. Ficamos, pois, suspensos nos acenos ramificados da condicional e nas convenientes lacunas das reticências, sem, entretanto, poder contar com o verbo principal, que permanece ausente...

Se tu viesses ver-me hoje à tardinha

A essa hora dos mágicos cansaços,

Quando a noite de manso se avizinha,

E me prendesses toda nos teus braços...

Quando me lembra: esse sabor que tinha

A tua boca... o eco dos teus passos...

O teu riso de fonte... os teus abraços...

Os teus beijos... a tua mão na minha...

Se tu viesses quando, linda e louca,

Traça as linhas dulcíssimas dum beijo

E é de seda vermelha e canta e ri

E é como um cravo ao sol a minha boca...

Quando os olhos se me cerram de desejo...

E os meus braços se estendem para ti... (p.218)

Todo o poema se perfaz, portanto, como um apelo inconcluso, por isso mesmo sedutor, se equilibrando numa corte ambígua de mostrar e esconder, num ritmo indeciso entre a máscara e a ostentação. Se ocultar é, de fato, uma função 
Maria Lúcia Dal Farra

primária da vida, uma necessidade ligada à economia e à constituição de reservas, como nos ensina Bachelard, vemos agora como Florbela conhece o inestimável valor dessa estratégia quando aplicada às relações amorosas. ${ }^{8}$ Invocando uma simbólica sempre enigmática do crepúsculo, intermediária e lusco-fusco, aliás, deveras propícia a tais atividades deslizantes, ela devaneia sobre a vinda do amado, chamando, primeiro, a lembrança da passada experiência amorosa com ele e, depois, entremostrando aquilo que ela já agora tem pra lhe ofertar. De todas as suas moradas interiores, a boca é a mais apreçada, toda rubra, de seda, cantante, risonha, persuasiva, traçando sutilmente as linhas dum beijo - metáfora do cravo ao sol. E, a partir daqui, Florbela se prepara para a intimidade que virá, cerrando os olhos à espera do que não disse: enfim, da oração principal que, de certeza, apenas de nós é furtada, mas que fica, em definitivo, acionada para ser vivida doravante tão-só pelos amantes.

Em contrapartida, o proferido que se transmuta em elíptico pode ser apanhado no soneto "Volúpia" de Charneca em flor. Eis aqui uma peça que privilegia o tato, com seu corolário, aliás pleonástico, de frêmitos vibrantes, bem como a simbólica alimentar que, através da imagem transubstanciada do vinho, identifica o corpo feminino em ofertório. Resulta daí uma liturgia da volúpia, onde paganismo e divindade se entrelaçam para vencer o destino do corpo que, desde o nascimento prometido à

8 Cf. BAChelARD, Gaston. Os devaneios da intimidade material. A terra e os devaneios do repouso. São Paulo, Martins Fontes, 1990, pp.7-44. (Trad.: Paulo Neves.) Aproveito também para citar outras obras de Bachelard, das quais me valho, para este texto: A casa natal e a casa onírica, pertencente à obra citada, pp.75-99; A poética das asas, O sonho de vôo. Nietzsche e o psiquismo ascensional. In: $O$ ar e os sonhos. Ensaio sobre a imaginação do movimento. São Paulo, Martins Fontes, 1990, respectivamente pp.65-89, 16-64, 127-162 (Trad.: Antonio da Pádua Danesi); A poética do espaço. In: Os pensadores. Vol. XXXVIII, São Paulo, Abril Cultural, 1974, pp.339-514 (Trad.: Antônio da Costa Leal e Lídia do Valles Santos Leal); A ordem das coisas. In: O direito de sonhar. São Paulo, DIFEL, 1985, pp.151-156 (Trad.: José Américo Motta Pessanha). 
Florbela erótica

morte, fica desviado, no poema, para as mãos e para o domínio do amado.

A porção transgressiva do erotismo, que se entremostra desafiando o poder do Fatum, reaparece em certo prazer um tanto perverso dos beijos de maldade que Florbela endereça ao amante, no devaneio do pontiagudo e do afiado, contido nos dedos do sol cravados como lanças no peito dele, metáfora dos seus próprios, e nos círculos dantescos com que ela envolve felinamente o amado.

Sem dúvida, a principal personagem desta peça é o seu corpo, flexionado segundo o diapasão de diferentes registros, definido metafisicamente como a "sombra entre a mentira e a verdade", metereologicamente como a vigorosa nuvem capaz de desviar o vento norte, liturgicamente como o vinho forte, selvagemente como dotado dos sortilégios do gato, e literariamente como incorporador dos variados estágios de sofrimento e prazer concernentes à Divina Comédia:

No divino impudor da mocidade,

Nesse êxtase pagão que vence a sorte,

Num frêmito vibrante de ansiedade,

Dou-te o meu corpo prometido à morte!

A sombra entre a mentira e a verdade...

A nuvem que arrastou o vento norte...

- Meu corpo! Trago nele um vinho forte:

Meus beijos de volúpia e de maldade!

Trago dálias vermelhas no regaço...

São os dedos do sol quando te abraço,

Cravados no teu peito como lanças!

E do meu corpo os leves arabescos

Vão-te envolvendo em círculos dantescos

Felinamente, em voluptuosas danças... (p.238)

O devaneio do rubro nomeia aqui as dálias que essa mulher traz no regaço, cujas pétalas tomam a feição de tentáculos prontos a envolverem o amado, insinuando uma imagem poderosa dos 
seios que se cravam no peito dele quando ela o abraça. Rito de dádiva do próprio corpo, o poema, todavia, se suspende elipticamente, quando a preparação para o ato erótico se encerra.

Já em "Horas rubras" do Livro de Sóror Saudade, a alta temperatura amorosa do soneto não se disfarça e alcança o seu título, tingindo de volúpia até mesmo o transcorrer do tempo em que a amante se oferece ao amado. Aliás, se ela assim procede é porque parece acompanhar o movimento do cosmos inteiro que, na noite, se acha entregue ao cio, e cujo gozo explode em verdadeiros cataclismos de astros dementes, tombando em fogo, em estilhaços de prata do luar, que se espalham, lânguidos, como beijos pelas estradas afora, expondo o espetáculo da cópula entre o céu e a terra. A amante, contaminada pela ardência noturna, pelo silêncio aprofundado e vertical, entrecortado por ruídos sensuais de risos arrebatados, busca se entregar ao seu Poeta, na oferta de um beijo que parece ser tudo o que ele tem procurado pela vida. Os lábios dela são ditos lagos brancos, seus braços levitam vestidos de lua, de modo que ela encarna, ao mesmo tempo, a chama e a neve:

Horas profundas, lentas e caladas

Feitas de beijos sensuais e ardentes,

De noites de volúpia, noites quentes

Onde há risos de virgens desmaiadas...

Oiço as olaias rindo desgrenhadas...

Tombam astros em fogo, astros dementes,

E do luar os beijos languescentes

São pedaços de prata p'las estradas...

Os meus lábios são brancos como lagos...

Os meus braços são leves como afagos,

Vestiu-os o luar de sedas puras...

Sou chama e neve branca e misteriosa...

E sou, talvez, na noite voluptuosa,

Ó meu Poeta, o beijo que procuras! (p.196) 
Florbela erótica

Nesse íntimo devaneio de tintura, que envolve o negro, o branco e o vermelho, perpassa, como se vê, uma dialética do quente e do frio, que também diz respeito ao tato, à audição, à visão e ao gosto, já que o beijo doado tem feição de arquétipo alimentar. Os signos de pureza dessa entrega se pressentem na configuração da seda dos afagos, na brancura da boca, no arroubo das virgens que desmaiam de prazer. A incidência dos sentidos é, pois, em extremo forte, e a presença do masculino e do feminino nesse ato poético de fusão amorosa do cosmos vem exposto pelas "olaias", essa potência floral, vermelha $e$ leguminosa, ao mesmo tempo partícipe de ambos os gêneros. Mas o que marca deslumbrantemente a intuição estética de Florbela é o enlace das três sublinhadas cores. Se o estampido ouvido dentro do poema é o da explosão, é porque, com toda a evidência, tratase de uma convulsão universal, cujo pavio foi aceso pela pólvora que, nada mais é senão a mistura do negro carvão com o homem vermelho e com a mulher branca. Carvão, enxofre e sal se aliam para produzir a pólvora, valor cósmico insigne, que realiza a síntese das potências do negro, do vermelho e do branco. ${ }^{9}$

A mesma ardência sensual se dá em "Toledo", de Charneca em flor, poema que realça, de um lado, a luminosidade - caso ímpar em se tratando de ato erótico, visto que a preferência poética de Florbela se situa sempre no crepúsculo e durante o outono. De outro lado, faz espécie neste poema a qualidade da privacidade amorosa, que é obtida contra toda a expectativa pública. Desse modo, ele realiza a conquista absoluta de uma

9 Cito Bachelard: "Em sua Histoire de la chimie, onde consegue determinar melhor do que todos os seus predecessores a dualidade entre a química $e$ a alquimia, Fierz-David indica com acerto uma valorização de cores substanciais na origem da invenção da pólvora. O negro carvão "como matéria prima foi misturado ao enxofre (o homem vermelho) e ao sal (a mulher branca).' A explosão, valor cósmico insigne, foi o signo resplandecente do nascimento do 'jovem rei'. Não se pode deixar de reconhecer aqui a ação de uma certa causalidade das cores; a pólvora realiza uma síntese das potências do negro, do vermelho e do branco". Cf. BACHELARD, Gaston. A terra e os devaneios... Op. cit, pp.35-36. 
cidade para uso pessoal e íntimo do casal, que a obtém deserta e ensolarada, enquanto ambiência perfeita e caliente para o desenrolar de um apogeu sexual.

Também chama a atenção, de imediato, que Florbela tivesse escolhido um lugar estrangeiro para tal expansão erótica, espaço tomado pela cor rubra, mineral, situada no lapidário do rubi que, todavia, é diluído, enquanto metáfora de Toledo, numa taça de ouro ardente. Esse devaneio de tintura e de formas, associado à simbólica do abrandamento de uma substância com o fito de expressar um espaço subjugado para o amor, conduz-nos à imagem da operação alquímica produtora de um vinho único - o afrodisíaco. A dinâmica do estranho e do familiar, muito própria ao ato erótico, também se asila nesse espaço, visto que a dita cidade estrangeira se situa às margens de um rio familiar, do rio da sua aldeia, como o diria Pessoa - do esmalte azul do Tejo a flamejar ao longe, como diz o soneto.

A simbólica das cores começa, de novo, a ganhar saliência, e o preto, muito embora ausente já que não há sequer a sombra de um gesto dentro dessa felicidade expansiva, se impóe como a cor íntima do tonos amoroso, visto que o único breque no interior do ritmo embriagador do poema é executado apenas para considerar que "Um grande amor é sempre grave e triste". Tudo se passa a céu aberto, em vasta luz, em pleno sol, em meio a matizes que percorrem o vermelho, o amarelo, o branco, o azul e o dourado - estes dois últimos, cores de Nossa Senhora da Conceição, tão recorrentes em Florbela. Também o tato e a vibração, necessários à cerimônia de imposição das mãos, que tremem, sobre o corpo amado feito de âmbar, bem como o odor do jasmineiro em flor, em que Florbela se encarna, apenas para ser desfolhada com beijos - complementam o repertório dos sentidos aguçados para a paixão. A imensidão deserta à mercê do casal confere amplitude horizontal e vertical à volúpia que, por fim, ascende numa torre para gritar o seu êxtase aos céus. 
Florbela erótica

Diluído numa taça de oiro a arder

Toledo é um rubi. E hoje é só nosso!

O sol a rir... Viv'alma... Não esboço

Um gesto que me não sinta esvaecer...

As tuas mãos tateiam-me a tremer...

Meu corpo de âmbar, harmonioso e moço

É como um jasmineiro em alvoroço

Ébrio de sol, de aroma, de prazer!

Cerro um pouco o olhar onde subsiste

Um romântico apelo vago e mudo

- Um grande amor é sempre grave e triste.

Flameja ao longe o esmalte azul do Tejo...

Uma torre ergue ao céu um grito agudo...

Tua boca desfolha-me num beijo... (p.227)

Muito embora Florbela não pareça contar com nenhuma dificuldade em nos comunicar o seu prazer, as considerações a respeito da impossibilidade de registro do êxtase erótico transparecem num poema de Reliquiae, sintomaticamente intitulado "Divino instante". Assim, contra a convicção dos seus tercetos acerca da incapacidade humana de fixação desse efêmero de graça, seus quartetos dedicam-se à sensação de desprendimento do mundo e do magnífico torpor, tão peculiar a tal arrebatamento. O bizarro é que nesse momento de consignação daquilo que não se deixa apreender, Florbela acaba por se deparar com a aliança entre Eros e Thanatos. Porque, na medida em que busca capturar esse átimo divino, ela se reconhece como urna de bronze, como morta inerte e fria, como boca fechada, valores relativos à imersão no devaneio da vida submergida, muda e recôndita, numa dinâmica situada em terreno que se limita com a morte. Mas, certamente porque ainda se sinta mergulhada nesse próprio estágio letárgico da volúpia que tenta descrever nos dois primeiros quartetos, é que se tornem, para Florbela, impraticáveis a apreensão do beijo que lhe queima o corpo, o registro do instantâneo das pálpebras do amante 
descidas sobre os olhos desmaiados de prazer. De maneira que o soneto, enfatizando a sua própria impotência de expressão, articula, em verdade, os valores mais profundos e significativos da epifania sexual.

Ser uma pobre morta inerte e fria,

Hierática, deitada sob a terra,

Sem saber se no mundo há paz ou guerra,

Sem ver nascer, sem ver morrer o dia,

Luz apagada ao alto e que alumia,

Boca fechada à fala que não erra,

Urna de bronze que a Verdade encerra,

$\mathrm{Ah}$, ser Eu essa morta inerte e fria!

Ah, fixar o efêmero! Esse instante

Em que o teu beijo sôfrego de amante

Queima o meu corpo frágil de âmbar loiro;

Ah, fixar o momento em que, dolente,

Tuas pálpebras descem, lentamente,

Sobre a vertigem dos teus olhos de oiro! (p.284)

Uma outra dimensão erótica, a do retiro sensual, a do casulo, se encontra, por exemplo, num outro poema de Charneca em flor. O delicioso devaneio acerca da intimidade domiciliada, acionado pelo soneto "A nossa casa", parece se desempenhar como um assentamento de terreno, como uma espécie de rito de apaziguamento do chão onde essa morada deverá ser construída. Na procura ansiosa por ela, o calor do desejo é já suficiente para, num átimo, construí-la, visto que a casa devaneada é o bem mais prezado do mundo, o mais invejado, lugar de repouso, de proteção contra a fluidez da vida externa. Concebida como o refúgio, neste caso, aéreo, ela se alça como um ninho, onde a doçura e a leveza do beijo são comparados à diafaneidade da asa. Fala-se, aqui, então, de uma casa leve, de uma existência volátil assediada na simbólica do sótão, espaço da sublimação e da vida recolhida. 
Florbela erótica

A nossa casa, Amor, a nossa casa!

Onde está ela, Amor, que não a vejo?

Na minha doida fantasia em brasa

Constrói-a num instante, o meu desejo!

Onde está ela, amor, a nossa casa,

O bem que neste mundo mais invejo?

O brando ninho aonde o nosso beijo

Será mais puro e doce que uma asa?"

Mas, enquanto a sonhada casa desenraizada e erguida pela fantasia não assenta suas fundações no solo da realidade, ao résdo-chão, os amantes, de mãos dadas, calcam os pés sobre a terra em busca do seu próprio fundeamento. Assim, num exercício de estabelecimento do chão, percorrem caminhos que confluem, afinal, para uma terra de rosas, para um jardim, numa simbólica do paradisíaco que é, de fato, um assentamento para ao acalentado devaneio. E daí que a dinâmica do sótão e do porão se entremostre na decisão de tomar posse, de habitar, agora e em definitivo, a gruta, a caverna, a raiz, visto que Florbela sonha que mora - tão bom! - dentro dele, e que ele mora - tão bom! dentro dela. Assim, a casa que se queria construir, organizada em altura pela topografia do sonho, se aconchega no onirismo do corpo, onde encontra a sua felicidade maior de sede fusional oculta e íntima.

Sonho... que eu e tu, dois pobrezinhos,

Andamos de mãos dadas, nos caminhos

Duma terra de rosas, num jardim,

Num país de ilusão que nunca vi...

E que eu moro - tão bom! - dentro de ti

E tu, ó meu Amor, dentro de mim... (p.224)

Veja-se que o erotismo florbeliano, pronto a eclodir no espetáculo dos cataclismos e das convulsões siderais, também é 
capaz de se recolher, silencioso e mudo, na zona de intimidade - a mais recôndita.

Tomo como um último exemplo para concluir esse pequeno trajeto de amostragem da sensualidade que escandalizou o mundo salazarista, um soneto sem título, localizado nos esparsos de Florbela, que tem o dom de aproximar a temática do erotismo àquela da busca de um outro país, enredando-as de tal maneira que, como se verá mais tarde, já no contexto do Diário do último ano, torna impossível a dissociação entre Eros e Thanatos.

O soneto, que é identificado pelo seu primeiro verso "Há nos teus olhos de dominador", explora uma alegoria, que se descerra no caminho para o novo mundo - portanto, numa simbólica das expedições dos descobrimentos portugueses. Por sua vez, dotado de todos os traços do herói, o amado e capitão segue "um misterioso ideal divino e humano" e navega por um mar calmo, horizontal, puro, sem acidentes, comandando a sua barca que, assim ritmada, se torna apta a acalentar devaneios.

Dentre esses, o do berço cósmico que é o mundo e a simbólica da imensidão embalada conferem uma deliciosa alternância de movimentos a essa navegação, a esse singrar de espaços à procura de regiões inaugurais, para onde a amada solicita ir, mesmo que como simples tripulante, disposta, todavia, a tornar-se audaz navegante capaz de alcançar, com o amado, esses distantes Reinos:

Há nos teus olhos de dominador,

No teu perfil altivo de romano,

No teu riso de graça e de esplendor

Um misterioso ideal divino e humano.

Cruz de Cristo sangrando sobre o pano

Das velas altas, lá vai, sobre o fragor

Dum mar sereno, cristalino e plano,

A tua barca de conquistador!

Eu quero ir contigo a esses distantes

Reinos! Deixa-me erguer as brancas velas, 
Florbela erótica

Ser um dos teus audazes navegantes!

Meus olhos cegos são dois poços fundos...

- Conta-me o céu! Ensina-me as estrelas!

Mostra-me a estrada dos teus Novos Mundos! ${ }^{10}$ (p.327)

Atravessa, entretanto, o itinerário da caravela dos descobrimentos, uma semântica outra. A amada quer erguer as brancas velas para que o sopro as infle, dando curso ao devaneio, de modo a que a embarcação prossiga em busca das estrelas e do céu que o amado está prestes a lhe ensinar, a ela, cujos olhos são cegos: "dois poços fundos". Sem a bússola do amado, portanto, a terra do sonho jamais será alcançada e o conhecimento acenado será em vão. Mas é muito provável que essa descoberta esteja prestes a ocorrer, visto que sobre o pano das altas velas já sangra a cruz de Cristo. A simbólica do sangue na vela branca atravessada pelo vento forte orienta que o conhecimento do mundo inexplorado torna-se metáfora da defloração. Ação embalada num berço de felicidade sem limites, graças à expansão oferecida pela água ritmada e infinita, o descobrimento desse país de eleição alcança uma amplitude oferecida também pela verticalidade, presente nos mastros das altas velas, nos poços dos olhos da amada, no céu, nas estrelas, o que torna ascendente $e$ impulsionada a própria estrada marítima para esses Novos Mundos.

Resta, agora, precisar melhor, à luz de outros subsídios, quais as fronteiras, os acessos, a cartografia que orienta Florbela na descoberta desses "distantes Reinos", desses "Novos Mundos", mapa que lhe permite o descerramento desse "ideal" que é, ao mesmo tempo, "divino e humano".

\footnotetext{
${ }^{10}$ Ajunto, aqui, a informação de que esse soneto sem título traz, em seu autógrafo (pertença do espólio do Grupo Amigos de Vila Viçosa, doado à entidade por Mário Lage, derradeiro marido de Florbela), a data de "Outubro 1930", pertencendo, portanto, à última fase da vida da poetisa, que morreria praticamente um mês depois.
} 